\title{
STATISTICAL ELOXAL COATING MICROHARDNESS ANALYSIS
}

\author{
BADIDA, M[iroslav]; GOMBAR, M[iroslav]; KMEC, J[an] \& SOBOTOVA, L[ydia]
}

\begin{abstract}
In order to improvethe mechanical properties ofthe excludedlayer by anodic oxidationof aluminum on material EN AW-1050 H24, there wasinvestigated the micro-hardness ofexcludedlayeras a function ofphysical and chemical factorsinvolved inthe anodicoxidationprocess. The constantcurrent density wasJA $=3 A \cdot \mathrm{dm}^{-2}$ in the electrolyte,constituted bysulfuric acidandoxalic acid. The emphasis was put on the impact of allconsideredactive factors and theirinteractions in this process. The model of studied dependence was designedbasedonmathematical andstatistical analysis ofmatrix with experimentalobtained data of compositerotation plan of experimentwith fiveindependentvariablesfactors (amount of sulfuric acid in the electrolyte, amountof oxalic acidin the electrolyte, temperature of electrolyte, anodizingtimeand appliedvoltage). Theexperimentwascarried out on 44 separateattempts withcurrent change of values of individualfactors underdefined levels in eachimplementation.
\end{abstract}

Keywords:Aluminium anodic oxidation, microhardness, Design of Experiments

\section{INTRODUCTION}

In many applicationsof structuralcomponentsmade of aluminumandits alloys, which are governed byanodic oxidationhave a keyrole inthe mechanical properties, especiallymicro-hardnessandwear resistance. Depending on theconditions ofanodizing, these propertiescan varywidely, so research on the impactof chemical, physicalandtechnological factorson the resultingAAOlayershave gainedmuch attention. Basic informationrelated tothesedependences we canfound inthe literature[1], [2], [3].

Most experimentalworks, in the field of(micro) hardness, are performedin the "heavy" anodizingconditions, under whichwe may includelowtemperatures of the electrolyte and also specialchemicalcomposition of theelectrolytes.But their primary purposeis to identify thehigh-values ofmicrolayers[4]. Accordingto Sccot[5], theanodicoxidationin sulfuric acidat a constantcurrentdensity 4-2 A.dmwas variedat temperatureranges from $-5^{\circ} \mathrm{Cto}+15^{\circ} \mathrm{C}$, themicrohardnessis affectedbysuch conditionson a small scale, with whatis related towear resistance.

Another study published by Koizumi[6], which deals with theanodic oxidationof aluminum in thegalvanicstaticmodeat currentdensities of 1 to $8 \mathrm{~A} \cdot \mathrm{dm}^{-2}$ in the electrolyte,constituted bysulfuric acidandoxalic acidat electrolytetemperaturesbetween $-5^{\circ} \mathrm{C}$ to $+20^{\circ} \mathrm{C}$, claimsthat theexaminedinterval isthe micro-hardnessand wear resistance nearly constantthe temperature range $-5^{\circ}$ Cto $+5 \circ \mathrm{C}$, regardless of the appliedcurrent density. Furthermore, this study argues thatin an increase temperature of the electrolyte occurs gradually reducing the value of themicro-hardness. The decline is more pronounced at the using oflowercurrent densityvalues. This argument, however, should be takenwith caution, because the anodizing time in this experiment was always constant, it means 45 minutes, regardless of usedcurrent density. As a result, there were created and then evaluated the layerswith greater thickness, which one directly affects on thefinal value of microhardnessandwear resistance[7] [8] [9].

The oxide layers with the thickness of $25 \mu \mathrm{m}$ or more, formed in the electrolyte, constituted by sulfuric acid at temperatures in the range $+15^{\circ} \mathrm{C}$ to $+30^{\circ} \mathrm{C}$ and at various applied current densities (1-4 A.dm ${ }^{-2}$ ), according to some authors [10], [11], are characterized by a softer outer layer, which reduces the transparency of the layer and its resistance to wear. Such effects have been the similar on the value of micro-hardness according to mentioned works.

Regarding of theinfluenceof electrolytetemperatureon themicrostructure ofanodicformed layers atpotentiostaticconditions, someauthorsargue thatthe increasingtemperature of the electrolyteleads to adecreasingvalue ofthe ratio ofthe thicknessof the barrier layerto the appliedvoltage together with thereduction ofthe porediameter[12]. Recent studiesshow thatthe thickness ofthe barrier layeris independent on theelectrolyte temperatureand appliedelectric potential[13] [14]. Usually, there isreceived theconceptof increased level ofthe chemical dissolution of created oxide layer,generatedat elevatedtemperatureof the electrolyte, whichleads tothe conical shape ofpores with theirincreasingdiametertowards to the surface[15], so the dissolutionof the materialof the wallsof pores is resulting in increasing oflayer porosity.

Based onthereviewof publishedpapers from the area of the mechanical properties ofanodicformed layers, focusing particularly on themicro-hardness, the emphasis is puttingon theinfluenceof electrolytetemperatureand appliedcurrent densitywithout consideringof other factors.Therefore, in this studyis, through aplannedexperimentandsubsequentmathematical andstatistical analysis,observednot onlyeffectof the electrolyte temperature, but alsorecentinfluenceof next chemical and physicalfactors affectingboth onthethickness andon the mechanical properties oflayersformedby anodicoxidation ofaluminumin an electrolyteconstituted bysulfuric acidandoxalic acid.The effect oftemperature, due to thecomplexity ofthe anodizingprocess ofaluminum and its alloys, should be monitoredin interactionwith otherfactorsthat were 
consideredin a particularcurrent densityandnotaloneasthe onlyeffectinfluencing onendpoint parameter.

\section{ALUMINIUM ANODIC OXIDATION}

Anodic oxidation represents one of important methods of aluminium and its alloys surface finish. It represents an exceptional combination of scientific and natural aspects for one of the most effective kinds of surface finish creating. It is an electrochemical process which reinforces and firms up a naturally created oxidic layer. A surface microscopical structure as well as metal crystal structure changing near the surface is achieved by anodic oxidation. By final finishing procedure, the second hardest substance (after diamond hardness) is obtained. The surface layer is porous and it is a part of the metal. The layer also enables dyestuff or oil to penetrate and thus it is practicable to get various coloureffects and to improve sliding properties.

The first hypothesis about anodic oxide layers forming mechanics was published in 1932. Till recent days no generally accepted theory totally clarifying this process has been developed.One of the theories [16] clarifies oxide layer formation. The theory is based on the fact that hydrogenium is produced on the cathode of insoluble metal and in the same time alcalinity grows due to hydroxyl anion concentration rising:

$$
\begin{aligned}
& \text { Cathode: } 2 \mathrm{H}_{2} \mathrm{O}+2 \mathrm{e} \rightarrow \mathrm{H}_{2}+2 \mathrm{OH}^{-} \\
& 2 \mathrm{H}_{3} \mathrm{O}^{+}+2 \mathrm{e} \rightarrow \mathrm{H}_{2}+2 \mathrm{H}_{2} \mathrm{O} \\
& \text { Anode: } \quad 2 \mathrm{Al}+6 \mathrm{OH}^{-} \rightarrow \mathrm{Al}_{2} \mathrm{O}_{3}+\mathrm{H}_{2} \mathrm{O}+6 \mathrm{e}^{-}
\end{aligned}
$$

In the beginning of the process, some amount of aluminium is dissolved due to passing electric current, but with aluminiumcations, and simultaneously a coating of insoluble aluminium hydroxide with electro-insulating properties is formed. This causes growth of electrical resistance and thus heating of layers. Following dehydratation generates a layer of aluminiumoxide.However, the anodic layer is not only the aluminium oxide one. It contains also water, anions of electrolyte, not oxidized impurities and alloy ingrediens which the basic material may contain.

Since 1953 the Keller's, Hunters's and Robinson's theory has been known. According to it, the oxide layer consists of hexagonal prizmatic cells with pores in their centres which are ended with approximately semiglobular bottom on the barrier layer, Fig. 1.

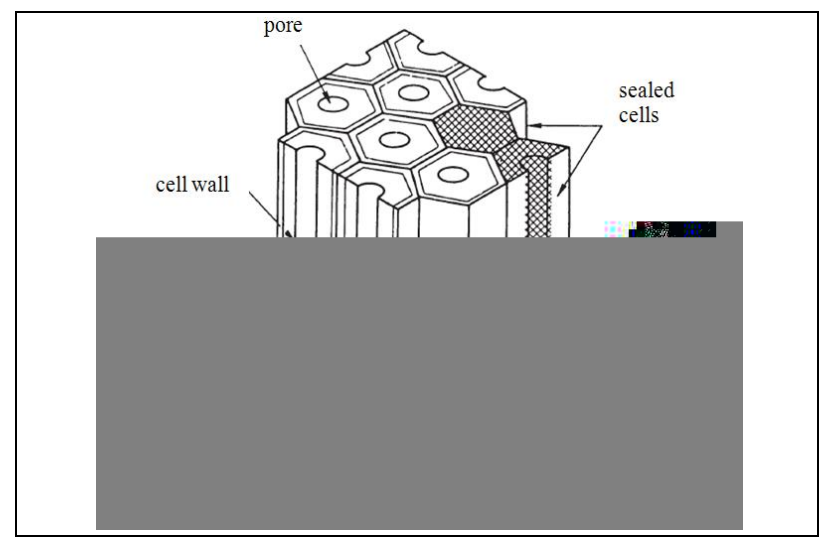

Fig. 1. Anodic oxidized layer structure [3]
More exact interpretation of anodic aluminium oxidation reaction mechanics theory is based on the assumption that aluminium is covered with aluminium oxide layer which creates a large amount of pores. During aluminium anodic oxidation process, a barrier layer is formed and thus a pore layer grows on it. Processes inside the layer are chemical and physical. Regressive dissolving of the layer at the bottom of pores is a process supported by electrical field; it is not case of simple chemical dissolving. Three components of current flow through the barrier layer: ion current, which causes layer porous part growth, ion current, which accompanies regressive layer dissolving process and electron current.

A base of another theory is existence of barrier layer planar inhomogeneity. This layer consists of areas with different electrical conductivity. Above low conductivity areas the oxide layer after reachning specific thickness cannot grow any more and pores begin being formed. On aluminium surface due to inserted voltage aluminiumcations and oxygenium anions are formed. They move in counter movement. Their reciprocal reactions proceed near porous bottom.

\section{EXPERIMENTAL PART}

High-quality preparation, realization and analysis of scientific and research experiments in laboratory experiments area requires mastering and learning a certain complex of knowledge and methodology known as DOE - Design of Experiments.

A frequent task of experiments in technology practice is to find out relations and links among certain quantities of studied process. It is important in cases when the process is very complicated and there is no sufficiently suitable mathematical-phsysical-chemical model for it. Common aim of the experiment is to determine how some factors infuence studied quantity often called a response. Required data for model design can be obtained by studied process quantities observing.[17],[18],[19] and [20].

For experiment realization a central composite plan with 44 experiments has been used. The experiments itself consisted of complete factor experiment type $2^{\mathrm{k}}$ where $\mathrm{k}$ represents numbers of factors - input independent variables and this complete factor experiment represents a core of the plan. Also, so called star-radialpoints and two measurements in experiment

\begin{tabular}{|c|c|c|c|c|c|c|c|}
\hline \multirow[t]{2}{*}{$\begin{array}{l}\text { Coded } \\
\text { factor }\end{array}$} & \multirow[t]{2}{*}{ Factor } & \multirow[t]{2}{*}{ Unit } & \multicolumn{5}{|c|}{$\begin{array}{c}\text { Factor level in natural } \\
\text { scale }\end{array}$} \\
\hline & & & $-2,37$ & -1 & 0 & +1 & $\begin{array}{r}+2,37 \\
\end{array}$ \\
\hline $\mathrm{X}_{1}$ & sulph. acid & $\mathrm{g} \cdot 1^{-1}$ & 9,19 & 85 & 140 & 195 & 270,81 \\
\hline $\mathrm{X}_{2}$ & oxalic acid & $\mathrm{g} \cdot 1^{-1}$ & 5,80 & 12 & 16,5 & 21 & 27,2 \\
\hline $\mathrm{x}_{3}$ & temperature & ${ }^{\circ} \mathrm{C}$ & $-1,78$ & 12 & 22 & 32 & 45,78 \\
\hline $\mathrm{X}_{4}$ & time & $\min$ & 1,22 & 15 & 25 & 35 & 48,78 \\
\hline $\mathrm{X}_{5}$ & voltage & $\mathrm{V}$ & 6,43 & 8,5 & 10 & 11,5 & 13,57 \\
\hline
\end{tabular}
schedule centre were used. Coded and natural intervals of individual factors are shown in Tab 1.

Individual experiments were carried out in random order at current density 3 A.dm ${ }^{-2}$. 



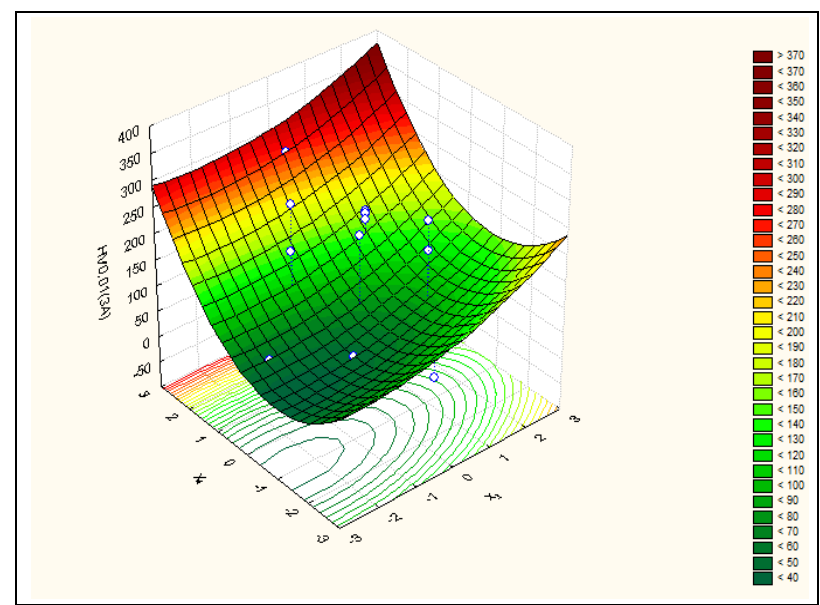

Fig. 5. Dependence between Factors $\mathrm{x}_{1}$ and $\mathrm{x}_{4}$

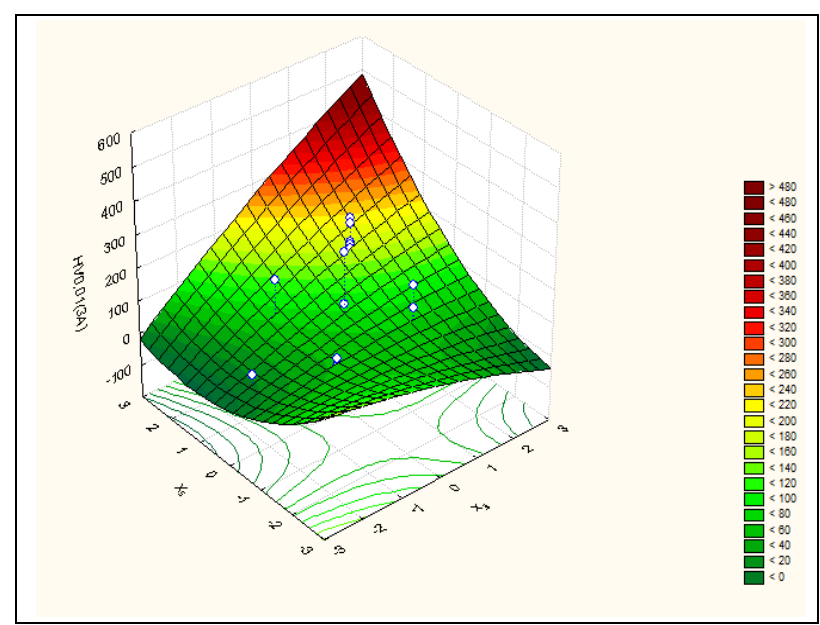

Fig. 6. Dependence between Factors $x_{3}$ and $x_{5}$

\section{CONCLUSION}

Anodic aluminium oxidation represents effective way of aluminium and alloy constructional parts surface finish. Apart from corrosion resistance and thermal insulation properties improvement, surface microhardness increases, too[21][22].However, it would be a mistake to assume that anodic oxidation means substantial increase of material hardness and thus aluminium mechanical resistance, because anodic layer thickness is $0.01-0.05 \mathrm{~mm}$. Coating microhardness increase itself depends on running conditions and especially on electrolyte composition, which is mostly sulfuric acid and water solution only. It depends also on time of anodic oxidation, electrolyte temperature and voltage. These general conclusions are supported by results of performed experiment whose results are valid only within intervals of used independent variable factors. This is the reason why it is necessary to carry out further experiments with extended intervals to obtain valid conclusions within complete scale of practically used working condidtions.

The resultsof experimental researchpresentedinthis paperareejectedpilot studyof research of mechanical propertiesof layers formedby anodicoxidation ofaluminum and its alloys. The team of authorsin the future plans to expand research for next practically used anodiccurrent densitiesas well asto extend the interval of parametersengagedin the technological processof anodic oxidation and to work with comparison ofresults at using ofelectrolytes with different chemical compositions.

\section{ACKNOWLEDGEMENTS}

The authors express their sincere thanks to Slovak Ministry of Education, Science, Research, project KEGA 049-TUKE- 4/2012 and project VEGA No. 1/ 0396/11

\section{REFERENCES}

[1] T. Aerts , Th. Dimogerontakis, I. DeGraeve , J. Fransaer, H. Terryn, Surface\&CoatingsTechnology 201 (2007) 7310-7317

[2] L.E. Fratila-Apachitei, J. Duszczyk, L. Katgerman, Surface and CoatingsTechnology 165 (2003) 309-315

[3] L. Vojkuvka , A. Santos , J. Pallarès , J. Ferré-Borrull , L.F. Marsal , J.P. Celis, Surface\&CoatingsTechnology 206 (2012) 2115-2124

[4] P.G., Sheasby, R., Pinner, TheSurfaceTreatment and FinishingofAluminium and itsAlloys, 6th Edition, ASM International, USA/ FinishingPublicationsLtd, UK, 2001, 743

[5] B.A. Scott, Trans. Inst. Met. Finish. 43 (1965) 1

[6] P.G. Sheasby, R. Pinner, TheSurfaceTreatment and FinishingofAluminium and itsAlloys, 6th Edition, ASM International, USA/ FinishingPublicationsLtd, UK, 2001, 761 (after S. Koizumi, S. Ninagawa, S.J. Ueda, J. Metal Finishing Society Japan 19 (1968) 504)

[7] K. Okubo, Met. Finish. 81 (1983) 63

[8] A.P. Gruar, D.R. Gabe, Trans. Inst. Met. Finish. 63 (1985) 1

[9] L.E. Fratila-Apachitei, J. Duszczyk, L. Katgerman, Surf. Coat. Technol.165 (2003) 309

[10] J. Herenguel, R. Segond, Rev. Met. 46 (1949) 377

[11] R.W. Thomas, Trans. Inst. Met. Finish. 59 (1981) 97

[12] J.P. O'Sullivan, G.C. Wood, Proc. R. Soc. Lond., A 317 (1970) 511

[13] Y.-C. Kim, B. Quint, R.W. Kessler, D. Oelkrug, J. Electroanal. Chem. 468 (1999) 121

[14] P.G. Sheasby, R. Pinner, TheSurfaceTreatment and FinishingofAluminium and itsAlloys, 6th Edition, ASM International, USA/ FinishingPublicationsLtd, UK, 2001, p 368(after K. Ebihara, H. Takahashi, M. Nagayama, J. Metal Finishing Japan 33 (1982) 4)

[15] F. Debuyck, M. Moors, A.P. VanPeteghem, Mater. Chem. Phys. 36 (1993) 146

[16] Badia,M.,Majerník,M.,Šebo,D.\& Hodolič,J., Engineering and manufacturing environment(Strojárska výroba a životné prostredie).Vienala,pp.253.ISBN 80-7099-695-1: Košice, 2001

[17] Zdravecká, E., Briančin, J. \& Fecsu, Š., Analysis of selected properties of PVD films. Scientific Bulletins of University of Technology. No. 253,pp. 305-310. ISSN 0209-2689, Rzeszów, 2008

[18] Štefko, R.,Slusarczyk, B., Kot, S. \&Kolmasiak, C., (2012). Transformation on Steel Products Distribution in Poland and Slovakia. Metalurgija, Vol: 51, pp. 133-136, ISSN 05435846, 2012

[19] Pavlenko, S., Hal'ko, J., Maščenik, J. \& Nováková, M.,Machine Parts Design with PC Support,Vol: 1. FVT TU, pp. 347, ISBN 978-80-553-0166-2: Prešov, 2008

[20] Maščenik, J.\&Gášpár, Š., (2011). Experimental Assessment of Roughness Changes in the Cutting Surface and Microhardness Changes of the Material S 355 J2 G3 after Being Cut by NonConventional Technologies In: Advanced Materials Research. Vol. 314-316, pp. 1944-1947. ISSN 1022-6680: Prešov, 2011

[21] Muránsky,J.,Badida,M. \& Hricová,B.,Ecodesign in Engineering(Ekodizajn v strojárstve).Elfa , pp.198, ISBN 978-80553-0788-6, Košice, 2011

[22] Wessely,E., Kralikova,R. \&Krupa,M.,Evaluation of work environment factors in mechanical engineering plants 2010. In: Annals of DAAAM for 2010 \& Proceedings of the 21th international DAAAM symposium.: DAAAM International ,pp. 219-220. - ISBN 978-3-901509-73-5 - ISSN 1726-9679- ,Vienna, 2010 